\title{
EFEKTIFITAS PENDAMPINGAN MINUM TABLET TAMBAH DARAH (TTD) OLEH KADER POSYANDU TERHADAP PENINGKATAN KADAR HB IBU HAMIL DI PUSKESMAS KOTA PALANGKA RAYA
}

\author{
Seri Wahyuni ${ }^{1}$ \\ ${ }^{1}$ Jurusan Kebidanan, Poltekkes Kemenkes Palangka Raya \\ Email: adilahidayat@gmail.com
}

\begin{abstract}
Background : Anemia is one of the indirect causes of maternal mortality. The Government of Indonesia has made efforts to overcome anemia, including by giving iron tablets to pregnant women. To improve maternal compliance in consuming iron tablet health care workers should include family / cadres in the supervision of food and medicine.

Objective : This study aims to know the effectiveness of accopaniment drinking iron tablet By Cadres Against Increasing Hb Level of Pregnant Women at Puskesmas Kota Palangka Raya.

Methods : This research is a quasi experimental design using "non randomized control group pretest-posttest design" approach. Sampling technique total sampling is with the number of samples of 62 people divided into 2 groups, 31 intervention groups and 31 control groups. In the intervention group involving cadres as moderate blood-boosting drink companions in the control group without blood-boosting companions. The analysis technique used for the intervention and control group is using the wilcoxon test.

Result : The result of intervention group statistic test get $p$ value $=0,000(<0,05)$. The results showed the influence of medication assistance to pregnant women to increase hemoglobin levels.

Conclusion and Suggestion: The involvement of posyandu cadres in the accompaniment of drink iron tablet in pregnant women can improve maternal compliance in taking bloodadded drugs so as to increase hemoglobin level and decrease the incidence of anemia.
\end{abstract}

Keywords: accopaniment, iron tablets, Pregnant women, Hb level

\begin{abstract}
ABSTRAK
Anemia merupakan salah satu faktor penyebab tidak langsung kematian ibu hamil. Pemerintah Indonesia sudah melakukan upaya penanggulangan anemia, di antaranya dengan memberikan TTD pada ibu hamil. Untuk meningkatkan kepatuhan ibu dalam mengkonsumsi tablet Fe petugas kesehatan haru mengikut sertakan keluarga/kader dalam pengawasan makan dan obat. Tujuan penelitian ini adalah Penelitian ini bertujuan untuk mengetahui efektifitas Pendampingan Minum Tablet Tambah Darah (TTD) Oleh Kader Posyandu Terhadap Peningkatan Kadar Hb lbu Hamil di Puskesmas Kota Palangka Raya. Penelitian ini adalah desain kuasi eksperimen dengan menggunakan pendekatan "non randomized control group pretest-postest design". Teknik pengambilan sampel total sampling yaitu dengan jumlah sampel sebanyak 62 orang yang dibagi menjadi 2 kelompok, 31 kelompok intervensi dan 31 kelompok kontrol. Pada kelompok intervensi melibatkan kader sebagai pendamping minum obat tambah darah (TTD) sedang pada kelompok kontrol tanpa pendamping minum obat tambah darah (TTD). Teknik analisa yang digunakan untuk kelompok intervensi dan kontrol yaitu menggunakan uji wilcoxon. Hasil uji statistik kelompok intervensi idapatkan nilai $p=0,000(<0,05)$. Hasil penelitian menunjukkan adanya pengaruh
\end{abstract}


pendampingan minum obat pada ibu hamil terhadap kenaikan kadar hemoglobin. Kesimpulan, keterlibatn kader posyandu dalam pendampingan minum obat tambah darah (TTD) pada ibu hamil dapat meningkatkan kepatuhan ibu dalam mengkonsumsi obat tambah darah sehingga dapat meningkatkan kadar hemoglobin dan menurunkan kejadian anemia.

Kata Kunci : Pendampingan, Tablet Tambah darah, Ibu hamil, Kadar Hb

\section{PENDAHULUAN}

Anemia merupakan salah satu masalah kesehatan di seluruh dunia terutama negara berkembang yang diperkirakan $30 \%$ penduduk dunia menderita anemia. Anemia banyak terjadi pada masyarakat terutama pada remaja dan ibu hamil. Anemia pada remaja putri sampai saat ini masih cukup tinggi, menurut World Health Organization(WHO) (2013), prevalensi anemia dunia berkisar 40-88\%. Jumlah penduduk usia remaja (10-19 tahun) di Indonesia sebesar 26,2\% yang terdiri dari 50,9\% laki-laki dan 49,1\% perempuan (Kemenkes RI, 2013).

Anemia merupakan salah satu faktor penyebab tidak langsung kematian ibu hamil. Angka Kematian Ibu (AKI) di Indonesia adalah tertinggi bila dibandingkan dengan Negara ASEAN lainnya. Perempuan yang meninggal karena komplikasi selama kehamilan dan persalinan mengalami penurunan pada tahun 2013 sebesar 289.000 orang. Target penurunan angka kematian ibu sebesar 75\% antara tahun 1990 dan 2015 (WHO, 2015). Jika perempuan mengalami anemia akan sangat berbahaya pada waktu hamil dan melahirkan. Perempuan yang menderita anemia akan berpotensi melahirkan bayi dengan berat badan rendah (kurang dari 2,5 $\mathrm{kg}$ ). Selain itu, anemia dapat mengakibatkan kematian baik pada ibu maupun bayi pada waktu proses persalinan (Rajab, 2009).

Anemia adalah keadaan yang ditandai dengan penurunan kadar hemoglobin $(\mathrm{Hb})$, jumlah sel darah merah dan gangguan dalam pemenuhan kebutuhan oksigen. Pada ibu hamil keadaan anemia ditandai dengan rendahnya kadar $\mathrm{Hb}$ yaitu kurang dari $11 \mathrm{gr} / \mathrm{dl}^{2}$. Terjadinya anemia disebabkan oleh berbagai factor. Faktor risiko terjadinya anemia adalah rendahnya asupan zat besi, absorpsi zat bes 1 rendah, yang dapat disebabkan aarı konsumsi makanan yang mengandung fitat dan fenol. Selain itu, terjadinya anemia juga disebabkan oleh kurang energy kronis (KEK) , umur kehamilan, paritas, status gizi, pola mengkonsumsi dan tingkat kepatuhan mengkonsumsi tablet Fe atau tablet zat besi oleh ibu hamil.

Pemerintah Indonesia sudah melakukan upaya penanggulangan anemia, di antaranya dengan memberikan TTD pada ibu hamil. Pendistribusian TTd 
juga telah dilakukan melalui Puskesmas dan Posyandu. Hasil Riskesdas 2010 menunjukkan bahwa 80,7\% perempuan usia 10-59 tahun telah mendapatkan TTD, untuk meningkatkan konsusi TTD, maka diperlukan system evaluasi dan monitoring yang dapat dipercaya.

Untuk meningkatkan kepatuhan ibu dalam mengkonsumsi tablet $\mathrm{Fe}$ petugas kesehatan haru mengikut sertakan keluarga dalam pengawasan makan dan obat, pengawasan minum obat merupakan kegiatan yang dilakukan untuk menjamin kepatuhan minum obat sesuai dengan dosis dan jadwal seperti yang telah ditetapkan (Maulana,2008).

Pemantauan minum obat (PMO) menurut Depkes (1999) adalah seseorang yang ditunjuk dan dipercaya untuk mengawasi dan memantau penderita dalam meminum obat secara teratur dan tuntas. PMO bisa berasal dari keluarga, tetangga, kader, tokoh masyarakat atau petugas kesehatan. Tugas pengawasan minum obat dirumah diantaranya, mengawasi minum obat harian dirumah, mencatat obat yang telah diminum dan mencatat keluhan yang dialami penderita, ikut serta dalam pengambilan obat, member motivasi supaya tida terjadi kegagalan minum obat serta menjadi penyuluhan kesehatan.

Berdasarkan profil kesehatan Provinsi Kalimantan Tengah pada tahun 2015 sebesar 80,33\% lebih rendah bila dibandingkan dengan cakupan $\mathrm{Fe} 90$ tablet padatahun 2014 sebesar 87\%. Ibu hamil yang umurnya kurang dari 20 tahun dan lebih dari 35 tahun, sekitar 74,1\% mengalami anemia. Bahaya anemia ini dapat mengancam keselamatan ibu serta janinnya, karena sangat beresiko mengalami pendarahan pada saat kehamilan, persalinan dan masa nifas. (Dinkes Kalimantan Tengah, 2014)

Berdasarkan profil dinas kesehatan kota Palangkaraya jumlah ibu hamil yang mendapatkan Fe1 sebanyak $6.157(91,55 \%)$ dan $\mathrm{Fe} 3$ (90 tablet) sebanyak 5.602 (83,3\%) menurun jika dibandingkan dengan tahun 2014 yaitu Fe1 sebanyak 5.932 (93,95\%) dan Fe3 (90 tablet) pada ibu hamil sebanyak 5.511 $(87,28 \%)$. Berdasarkan data dari Profil Kesehatan Kota Palangka Raya terdapat 2 Puskesmas dengan cakupan Fe3 paling rendah diantara puskesmas yang lain yaitu Puskesmas kalampangan dengan cakupan Fe3 sebesar 72,54\% dan Puskesmas Menteng cakupan Fe3 sebesar 72,15\% (Dinkes Kota Palangka Raya 2016).

Berdasarkan hasil wawancara dengan 10 orang ibu hamil di wilayah kerja puskesmas Kota Palangka Raya di peroleh informasi ternyata dari 7 orang ibu hamil tidak mengetahui manfaat tablet $\mathrm{Fe}$ bagi dirinya maupun janinnya dan selama kehamilan setiap Fe yang diberikan jarang dikonsumsi, karena ketidaktahuan manfaat, efek samping, cara dan waktu mengkonsumsi, Peneliti juga melakukan wawancara terhadap keluarga terutama suai ibu hamil, Suami mengatakan bahwa 
Efektifitas Pendampingan Minum Tablet Tambah Darah (TTD) Oleh Kader Posyandu Terhadap Peningkatan Kadar Hb lbu Hamil Di Puskesmas Kota Palangka Raya tidak pernah memperhatikan istrinya mendapatkan intervensi dari peneliti dan dalam mengkonsumsi tablet $\mathrm{Fe}$, karena ketidaktahuan manfaat tablet Fe bagi istri dan bayi dalam kandungannya.

Berdasarkan wawancara dengan bidan di Puskemas Kota Palangka Raya belum pernah dilakukan pemantauan minum obat Tablet Fe pada ibu hamil di Wilayah Kerja Puskesmas tersebut. Pemberian Tablet hanya langsung diberikan pada ibu hamil tanpa melibatkan suami dan keluarga. Sehingga dalam pemberian tablet $\mathrm{Fe}$ pada ibu tidak menunjukkan kenaikan $\mathrm{Hb}$ yang berarti, sehingga masih banyak kasus anemia yang ditemukan di Puskesmas Kota Palangka Raya.

Berdasarkan uraian diatas maka peneliti tertarik untuk melakukan penelitian dengan judul "Efektifitas Pendampingan Minum Tablet Tambah darah (TTD) oleh Kader Posyandu Terhadap Peningkatan Kadar Hemoglobin di Puskesmas Kota Palangka Raya.

\section{METODE PENELITIAN}

Penelitian ini adalah penelitian ini merupakan jenis penelitian analitik komparatif numerik berpasangan dengan desain penelitian quasi eksperimental dengan pendekatan non randomized control group pretest-postest design. Kelompok intervensi merupakan kelompok yang mendapatkan intervensi (treatment), sedangkan kelompok kontrol merupakan kelompok (control group) yang tidak pengambilan data dilakukan pada kedua kelompok. Populasi pada penelitian ini adalah Populasi pada penelitian ini adalah seluruh ibu yang hamil trimester III di Puskesmas Kota Palangka Raya periode Juli sampai oktober 2017.Sampel pada penelitian ini dibagi menjadi dua kelompok yaitu 31 pada kelompok intervensi dan 31 kelompok kontrol. Kelompok intervensi adalah ibu hamil yang dapat tablet tambah darah sebanyak 30 tablet selama 30 hari serta dengan pendampingan oleh kader, pada kelompok control mendapatkan tablet tambah darah sebanyak 30 tablet selama 30 hari tanpa pendampingan kader. Pada penelitian ini jumlah sampel dihitung menggunakan rumus berikut :

$$
n_{1}=\frac{[+Z)^{\left(Z \alpha{ }^{2}\right.}}{X_{1-X_{2}}}
$$

Pemilihan sampel dipilih dengan menggunakan consecutive sampling yaitu setiap pasien yang memenuhi kriteria inklusi dan eksklusi dijadikan sampel kelompok intervensi dan kelompok kontrol penelitian. Pengumpulan data dilakukan dengan menggunakan kuesioner terstuktur untuk mengetahui karakteristik responden yang meliputi umur, pendidikan, pekerjaan, pendamping minum obat, tingkat pengetahuan dan kepatuhan konsumsi. Sedangkan untuk kadar hemoglobin diukur dengan alat pemeriksaan $\mathrm{hb}$ digital sebelum dan sesudah intervensi. Untuk 
variable tingkat pengetahuan responden diukur dengan memberikan pertanyaan seputar anemia. Selanjutnya responden akan memilih salah satu jawaban yang paling benar. Seluruh jawaban yang benar dijumlahkan kemudian dikategorikan baik jika skor 76-100, sedang jika 56-75 dan kurang jika $<56$. Untuk Pengukuran tingkat kepatuhan dilakukan dengan memberikan kuesioner MMAS-8 (Morisky Medication Adherence Scale-8) yang berisi 8 pertanyaan untuk mengukur tinkat kepatuhan. Seluruh jawaban dijumlah dan diskoring, Kepatuhan Tinggi Jika Skor 0, Kepatuhan sedang jika skor 1-2, kepatuhan rendah jika lebih dari 2 .

HASIL

Tabel 1.1 Distribusi frekuensi usia ibu hamil

\begin{tabular}{lllll}
\hline \multirow{2}{*}{ Usia (tahun) } & \multicolumn{2}{c}{ Kelompok Intervensi } & \multicolumn{2}{c}{ Kelompok Kontrol } \\
\cline { 2 - 5 } & $\mathrm{N}$ & $\%$ & $\mathrm{n}$ & $\%$ \\
\hline 17 & 1 & $3.2 \%$ & 0 & 0 \\
18 & 0 & 0 & 1 & $3,2 \%$ \\
19 & 1 & $3.2 \%$ & 0 & 0 \\
20 & 4 & $12,9 \%$ & 1 & $3,2 \%$ \\
21 & 0 & 0 & 1 & $3,2 \%$ \\
22 & 1 & $3.2 \%$ & 0 & 0 \\
23 & 1 & $3.2 \%$ & 2 & $6,5 \%$ \\
24 & 0 & 0 & 0 & 0 \\
25 & 3 & $9,7 \%$ & 3 & $9,6 \%$ \\
26 & 3 & $9,7 \%$ & 2 & $6,5 \%$ \\
27 & 1 & $3,2 \%$ & 4 & 12,9 \\
28 & 2 & $6,5 \%$ & 1 & $3,2 \%$ \\
29 & 2 & $6,5 \%$ & 1 & $3,2 \%$ \\
30 & 3 & $9,7 \%$ & 3 & $9,7 \%$ \\
31 & 3 & $9,7 \%$ & 1 & $3,2 \%$ \\
32 & 1 & $3,2 \%$ & 0 & 0 \\
33 & 0 & 0 & 1 & $3,2 \%$ \\
34 & 2 & $6,5 \%$ & 6 & $19,4 \%$ \\
35 & 1 & $3,2 \%$ & 0 & 0 \\
36 & 1 & $3,2 \%$ & 1 & $3,2 \%$ \\
37 & 1 & $3,2 \%$ & 0 & 0 \\
38 & 1 & $3,2 \%$ & 1 & $3,2 \%$ \\
39 & 0 & 0 & 0 & 0 \\
40 & - & - & 1 & $3,2 \%$ \\
Total & 31 & $100 \%$ & 31 & $100 \%$ \\
& & & &
\end{tabular}


Tabel 1.2 Ukuran pemusatan dan ukuran penyebaran ibu bersalin usia reproduksi sehat dan usia berisiko

\begin{tabular}{lll}
\hline & $\begin{array}{l}\text { Kelompok } \\
\text { Intervensi }\end{array}$ & Kelompok Kontrol \\
\hline Mean & 27,42 & 28,52 \\
Median & 28 & 28 \\
Modus & 20 & 34 \\
Minimum & 17 & 18 \\
Maksimum & 38 & 40 \\
Standar deviasi & 5.584 & 5,732 \\
\hline
\end{tabular}

Berdasarkan hasil penelitian usia ibu hamil pada kelompok intervensi rata rata berusia 27,42 tahun dengan usia paling muda berusia 17 tahun dan paling tua 38 tahun. Sedangkan pada ibu hamil pada kelompok kontrol rata rata berusia 28,52 tahun dengan usia ibu bersalin paling muda berusia 18 tahun dan paling tua berusia 40 tahun.

Tabel 1.3 Distribusi frekuensi Pendidikan Ibu Hamil

\begin{tabular}{lllll}
\hline \multirow{2}{*}{ Pendidikan } & \multicolumn{2}{c}{$\begin{array}{c}\text { Kelompok } \\
\text { Intervensi }\end{array}$} & & Kelompok Kontrol \\
\cline { 2 - 5 } & $\mathrm{n}$ & $\%$ & $\mathrm{n}$ & $\%$ \\
\hline Tidak Tamat Sekolah & 0 & 0 & 1 & $3,2 \%$ \\
Tamat SD & 5 & $16,1 \%$ & 6 & $19,4 \%$ \\
Tamat SMP & 10 & $32,3 \%$ & 9 & $29 \%$ \\
Tamat & 12 & $38,7 \%$ & 11 & $35,5 \%$ \\
SMA/SMK/SLTA & 4 & $12,9 \%$ & 4 & $12,9 \%$ \\
Tamat & 31 & $100 \%$ & 31 & $100 \%$ \\
Diploma/Sarjana & & & & \\
Total & & & & \\
\hline
\end{tabular}

Sebagian besar sampel, baik kelompok intervensi maupun kelompok kontrol berpendidikan tamat SMA/SMK/SLTA sederajat. Pada kelompok Kontrol dijumpai 1 orang $(3,2 \%)$ tidak tamat SD dan terdapat pula pada 2 kelompok tersebut diatas yang tamat pendidikan diploma/sarjana masingmasing sebesar $12,9 \%$.

Tabel 1.4 Distribusi frekuensi pekerjaan ibu hamil

\begin{tabular}{lcccc}
\hline \multirow{2}{*}{ Pekerjaan } & \multicolumn{2}{c}{$\begin{array}{c}\text { Kelompok } \\
\text { Intervensi }\end{array}$} \\
\cline { 2 - 5 } & $\mathrm{n}$ & $\%$ & $\mathrm{~N}$ & $\%$ \\
\hline Ibu Rumah Tangga & 27 & $87,1 \%$ & 27 & $87,1 \%$ \\
PNS & 0 & 0 & 2 & $6,5 \%$ \\
Swasta & 3 & $9,7 \%$ & 2 & $6,5 \%$ \\
Honorer & 1 & $3,2 \%$ & 0 & 0 \\
Total & 31 & $100 \%$ & 31 & $100 \%$ \\
\hline
\end{tabular}


Berdasarkan tabel 1.4. Sebagian besar sampel, baik kelompok intervensi maupun kelompok kontrol memilik status pekerjaan sebagai ibu rumah tangga masing masing sebesar 27 orang (87\%). Pada kelompok Kontrol dijumpai 1 orang $(3,2 \%)$ memiliki status pekerjaan sebagai honorer.

Tabel 1.5 Tingkat Pengetahuan Ibu Hamil

\begin{tabular}{|c|c|c|c|c|c|c|c|c|c|c|}
\hline \multirow{3}{*}{$\begin{array}{l}\text { Tingkat } \\
\text { Pengetahuan }\end{array}$} & \multicolumn{4}{|c|}{ Kelompok Intervensi } & \multirow{3}{*}{$P$} & \multicolumn{4}{|c|}{ Kelompok Kontrol } & \multirow{3}{*}{$n$} \\
\hline & \multicolumn{2}{|c|}{$\begin{array}{l}\text { Sebelum } \\
\text { Intervensi }\end{array}$} & \multicolumn{2}{|c|}{$\begin{array}{l}\text { Sesudah } \\
\text { Intervensi }\end{array}$} & & \multicolumn{2}{|c|}{$\begin{array}{l}\text { Awal } \\
\text { penelitian }\end{array}$} & \multicolumn{2}{|c|}{$\begin{array}{l}\text { Akhir } \\
\text { penelitian }\end{array}$} & \\
\hline & $\mathrm{N}$ & $\%$ & $\mathrm{n}$ & $\%$ & & $\mathrm{n}$ & $\%$ & $\mathrm{~N}$ & $\%$ & \\
\hline Rendah & 9 & $29 \%$ & 0 & 0 & 0,000 & 9 & $29 \%$ & 0 & 0 & 0,007 \\
\hline Sedang & 14 & $45,2 \%$ & 0 & 0 & & 18 & $58,1 \%$ & 27 & $87,1 \%$ & \\
\hline Tinggi & 8 & $25,8 \%$ & 31 & $100 \%$ & & 4 & $12,9 \%$ & 4 & $12,9 \%$ & \\
\hline Total & 31 & $100 \%$ & 31 & $100 \%$ & & 31 & $100 \%$ & 31 & $100 \%$ & \\
\hline
\end{tabular}

Berdasarkan tabel 1.5. diketahui bahwa sebanyak $45 \%$ tingkat pengetahuan ibu hamil pada kelompok intervensi sebelum dilakukan penyuluhan adalah sedang. Setelah dilakukan intervensi, ibu hamil dengan tingkat rendah dan sedang menurun, berubah menjadi tingkat pengetahuan tinggi sebanyak 100\%. Di awal penelitian pada kelompok kontrol diketahui sebanyak $58,1 \%$ tingkat pengetahuan ibu hamil adalah sedang. Di akhir penelitian sebanyak $87,1 \%$ berubah menjadi tingkat pengetahuan pengetahuan sedang dan sebanyak $12,9 \%$ memilik tingkat pengetahuan tinggi. Pada kelompok intervensi dan kelompok kontrol memiliki perubahan tingkat pengetahuan yang bermakna sebelum dan sesudah dilakukan intervensi pada kelompok intervensi $(p=$ $0,05)$ dan kelompok kontrol $(p=0,007)$.

Tabel 1.6 Tingkat Kepatuhan Ibu Hamil

\begin{tabular}{|c|c|c|c|c|c|c|c|c|c|c|}
\hline \multirow{3}{*}{$\begin{array}{l}\text { Tingkat } \\
\text { Kepatuhan }\end{array}$} & \multicolumn{4}{|c|}{ Kelompok Intervensi } & \multirow{3}{*}{$P$} & \multicolumn{4}{|c|}{ Kelompok Kontrol } & \multirow{3}{*}{$p$} \\
\hline & \multicolumn{2}{|c|}{$\begin{array}{l}\text { Sebelum } \\
\text { Intervensi }\end{array}$} & \multicolumn{2}{|c|}{$\begin{array}{l}\text { Sesudah } \\
\text { Intervensi }\end{array}$} & & \multicolumn{2}{|c|}{$\begin{array}{l}\text { Awal } \\
\text { penelitian }\end{array}$} & \multicolumn{2}{|c|}{$\begin{array}{l}\text { Akhir } \\
\text { penelitian }\end{array}$} & \\
\hline & $\mathrm{N}$ & $\%$ & $\mathrm{n}$ & $\%$ & & $\mathrm{n}$ & $\%$ & $\mathrm{n}$ & $\%$ & \\
\hline Rendah & 26 & $83,9 \%$ & 2 & $6,5 \%$ & 0,000 & 30 & $96,8 \%$ & 29 & $93,5 \%$ & 0,317 \\
\hline Sedang & 5 & $16,1 \%$ & 26 & $83,9 \%$ & & 1 & $3,2 \%$ & 2 & $6,5 \%$ & \\
\hline Tinqai & 0 & 0 & 3 & $9.7 \%$ & & 0 & 0 & 0 & 0 & \\
\hline Total & 31 & $100 \%$ & 31 & $100 \%$ & & 31 & $100 \%$ & 31 & $100 \%$ & \\
\hline
\end{tabular}

Berdasarkan tabel 1.6. diketahui bahwa sebelum dilakukan intervensi, sebanyak 83,9\% tingkat kepatuhan ibu hamil mengkonsumsi tablet tambah pada kelompok intervensi memiliki tingkat pengetahuan rendah dan tidak ada yang 
Efektifitas Pendampingan Minum Tablet Tambah Darah (TTD) Oleh Kader Posyandu Terhadap Peningkatan Kadar Hb lbu Hamil Di Puskesmas Kota Palangka Raya

memiliki tingkat kepatuhan tinggi. Namun setelah dilakukan intervensi jumlah ibu hamil mengkonsumsi tablet tambah darah yang memiliki tingkat kepatuhan rendah menurun menjadi 6,5\%dan tingkat kepatuhan tinggi naik menjadi 9,7\%. Awal penelitian sebanyak 96,8\% kelompok kontrol memiliki tingkat kepatuhan rendah dan tidak ada yang memiliki tingkat kepatuhan tinggi. Pada akhir penelitian sebanyak 93,5\% ibu hamil masih memiliki tingkat kepatuhan rendah dan tidak ada yang memiliki tingkat pengetahuan tinggi. Pada akhir penelitian terjadi perubahan kepatuhan pada kelompok intervensi $(p=$ $0,000)$ dan pada kelompok kontrol tidak ada perubahan tingkat kepatuhan $(\mathrm{p}=$ $0,083)$.

Tabel 1.7 Perbedaan Kadar Hb

\begin{tabular}{|l|l|l|l|l|l|l|l|l|}
\hline \multirow{2}{*}{ No } & \multicolumn{3}{|c|}{ Kelompok Intervensi (PMO) } & \multicolumn{3}{c|}{ Kelompok Kontrol (Tanpa PMO) } \\
\cline { 2 - 8 } & Hb Awal & Hb Akhir & Selisih & PMO & $\begin{array}{c}\text { Hb } \\
\text { Awal }\end{array}$ & $\begin{array}{c}\text { Hb } \\
\text { Akhir }\end{array}$ & Selisih & Tanpa PMO \\
\hline 1 & 10.7 & 11.2 & 0.5 & Kader & 10.2 & 12.9 & 2.7 & - \\
2 & 10 & 12 & 2 & Kader & 10.8 & 12 & 1.2 & - \\
3 & 12 & 12.2 & 0.2 & Kader & 12 & 12.3 & 0.3 & - \\
4 & 10.2 & 10.6 & 0.4 & Kader & 9.6 & 10.9 & 1.3 & - \\
5 & 9.6 & 11.2 & 1.6 & Kader & 11.2 & 11.2 & 0 & - \\
6 & 8.8 & 10.8 & 2 & Kader & 12 & 12.8 & 0.8 & - \\
7 & 10 & 10.6 & 0.6 & Kader & 12 & 12.6 & 0.6 & - \\
8 & 11 & 13 & 2 & Kader & 10.2 & 11 & 0.8 & - \\
9 & 11 & 12 & 1 & Kader & 13 & 13 & 0 & - \\
10 & 10 & 12.6 & 2.6 & Kader & 13.2 & 13.5 & 0.3 & - \\
11 & 9.6 & 11 & 1.4 & Kader & 9.6 & 9 & -0.6 & - \\
12 & 9.4 & 10.1 & 0.7 & Kader & 10 & 11.8 & 1.8 & - \\
13 & 10.9 & 11.8 & 0.9 & Kader & 11 & 13.1 & 2.1 & - \\
14 & 11.2 & 12 & 0.8 & Kader & 9.6 & 8.6 & -1 & - \\
15 & 10.8 & 12.7 & 1.9 & Kader & 9.8 & 9 & -0.8 & - \\
16 & 10.2 & 10.8 & 0.6 & Kader & 12.5 & 13 & 0.5 & - \\
17 & 10.5 & 11.4 & 0.9 & Kader & 12 & 11.5 & -0.5 & - \\
18 & 10.1 & 11.6 & 1.5 & Kader & 12.6 & 10 & -2.6 & - \\
19 & 12 & 12.5 & 0.5 & Kader & 12.1 & 11.1 & -1 & - \\
20 & 11.6 & 12.4 & 0.8 & Kader & 10.4 & 10.9 & 0.5 & - \\
21 & 11.2 & 12.4 & 1.2 & Kader & 11.8 & 12 & 0.2 & - \\
22 & 9.6 & 10.2 & 0.6 & Kader & 13.5 & 13 & -0.5 & - \\
23 & 11.4 & 12 & 0.6 & Kader & 9.6 & 8.6 & -1 & - \\
24 & 11 & 11.8 & 0.8 & Kader & 11 & 10.2 & -0.8 & - \\
25 & 9.6 & 10.4 & 0.8 & Kader & 10.2 & 9.8 & -0.4 & - \\
26 & 9.4 & 10 & 0.6 & Kader & 10.2 & 10.2 & 0 & - \\
27 & 10.6 & 11.6 & 1 & Kader & 11 & 10.8 & -0.2 & - \\
28 & 12 & 13 & 1 & Kader & 10.2 & 9.6 & -0.6 & - \\
29 & 9 & 10 & 1 & Kader & 11.1 & 10 & -1.1 & - \\
30 & 10 & 12 & 2 & Kader & 10.2 & 10 & -0.2 & - \\
31 & 11 & 12 & 1 & Kader & 12.3 & 9.6 & -2.7 & - \\
& & & & & & & & \\
\hline
\end{tabular}


Seri Wahyuni

Tabel 5.7. memperlihatkan bahwa pada kelompk intervensi terjadi peningkatan kadar hemoglobin sebanyak 31 orang (100\%). Terlihat pada tabel 5.7 selilish kenaikan kadar hemoglobin dari 0,2-2,6 gr\%. Pada kelompok kontrol yang tidak dilakukan pendampingan minum obat, 15 orang $(48,4 \%)$ kadar hemoglobin menurun, 13 orang $(41,9 \%)$ kadar hemoglobin menurun dan 3 orang $(9,5 \%)$ tidak ada perubahan. Status anemia pada ibu hamil yang mengkonsumsi tablet tambah darah yang didampingi dan tidak didampingi dapat dilihat pada tabel 5.8 di bawah ini :

Tabel 1.8 Distribusi Frekuensi status anemia pada Ibu Hamil

\begin{tabular}{|c|c|c|c|c|c|c|c|c|c|c|}
\hline \multirow[t]{3}{*}{$\begin{array}{l}\text { Status } \\
\text { Anemia }\end{array}$} & \multicolumn{2}{|c|}{$\begin{array}{l}\text { Kelompok } \\
\text { (didampingi) }\end{array}$} & \multicolumn{2}{|c|}{ Intervensi } & & \multicolumn{4}{|c|}{$\begin{array}{l}\text { Kelompok Kontrol } \\
\text { (tidak didampingi) }\end{array}$} & \multirow{3}{*}{$P$} \\
\hline & \multicolumn{2}{|c|}{$\begin{array}{l}\text { Sebelum } \\
\text { Intervensi }\end{array}$} & \multicolumn{2}{|c|}{$\begin{array}{l}\text { Sesudah } \\
\text { Intervensi }\end{array}$} & \multirow[t]{2}{*}{$\mathrm{p}$} & \multicolumn{2}{|c|}{$\begin{array}{l}\text { Awal } \\
\text { penelitian }\end{array}$} & \multicolumn{2}{|c|}{$\begin{array}{l}\text { Akhir } \\
\text { penelitian }\end{array}$} & \\
\hline & $\mathrm{N}$ & $\%$ & $\mathrm{n}$ & $\%$ & & $\mathrm{~N}$ & $\%$ & $n$ & $\%$ & \\
\hline Tidak anemia & 12 & $38,7 \%$ & 22 & $71 \%$ & 0,000 & 17 & $54,8 \%$ & 15 & $48,4 \%$ & 0,811 \\
\hline Anemia & 12 & $38,7 \%$ & 9 & $29 \%$ & & 9 & $29 \%$ & 9 & $29 \%$ & \\
\hline Ringan & 7 & $22,6 \%$ & 0 & 0 & & 5 & $16,1 \%$ & 7 & $22,6 \%$ & \\
\hline Anemia & 0 & 0 & 0 & 0 & & 0 & 0 & 0 & 0 & \\
\hline $\begin{array}{l}\text { Sedang } \\
\text { Anemia Berat } \\
\text { Total }\end{array}$ & 31 & $100 \%$ & 31 & $100 \%$ & & 31 & $100 \%$ & 31 & $100 \%$ & \\
\hline
\end{tabular}

Berdasarkan tabel 5.7. Pada tabel diatas pada kelompok intervensi $\mathrm{Hb}$ awal sebelum intervensi yang terbanyak adalah tidak anemia dan anemia ringan masing masing sebesar 12 orang $(38,7 \%)$, dan 7 orang $(22,6 \%)$ anemia sedang. Pada akhir penelitian tidak anemia 22 orang (71\%) dan anemia ringan 9 orang (29\%) . diketahui bahwa sebelum dilakukan intervensi, sedan tidak ada ibu hamil yang menderita anemia sedang dan berat. Pada kelompok kontrol pada awal penelitian kadar hemoglobin ibu hamil yang terbanyak adalah tidak anemia 17 orang $(54,8 \%)$ dan anemia sedang 5 orang (29\%). Pada pada akhir penelitian jumlah ibu hamil yang tidak anemia menurun menjadi 15 orang $(48,4 \%)$ dan anemia sedang bertambah menjadi 7 orang (22,6\%). Pada akhir penelitian terjadi perubahan status anemia pada kelompok intervensi $(p=0,000)$ dan pada kelompok kontrol tidak ada perubahan status anemia $(p=0,811)$. 
Efektifitas Pendampingan Minum Tablet Tambah Darah (TTD) Oleh Kader Posyandu Terhadap Peningkatan Kadar Hb lbu Hamil Di Puskesmas Kota Palangka Raya

Tabel 1.9 Pengaruh Pendampingan Minum Tablet Tambah Darah (TTD)

oleh Kader Posyandu Terhadap Peningkatan kadar Hb ibu Hamil

Pada Kelompok Intervensi di Puskesmas Kota Palangka Raya

\begin{tabular}{ccccccc}
\hline $\begin{array}{c}\text { Kelompok } \\
\text { Intervensi }\end{array}$ & Mean & $\mathrm{N}$ & $\begin{array}{c}\text { Standar } \\
\text { Deviasi }\end{array}$ & Minimum & Maksimum & $\mathrm{P}$ \\
\hline $\mathrm{Hb}$ awal & 10,465 & 31 & 0,878 & 8,8 & 12,0 & 0,000 \\
$\mathrm{Hb}$ akhir & 11,545 & 31 & 0,899 & 10,0 & 13,0 & \\
\hline
\end{tabular}

Pada tabel 1.9 diatas dapat dilihat perbedaan nilai rata -rata kadar hemoglobin awal 10,465 sedangkan kadar hemoglobin akhir nilai rata-ratanya adalah 11,545. Dengan standar deviasi $\mathrm{Hb}$ awal penelitian 0,878 dan standar deviasi akhir penelitian 0,899. Dengan kadar hemoglobin paling rendah pada awal penelitian adalah 8,8 gr\% dan akhir penelitian kadar hemoglobin paling rendah naik menjadi 10,0 gr.\% Kadar hemoglobin ibu hamil pada awal penelitian paling tinggi adalah 12 gr\% dan akhir penelitian naik menjadi 13 gr\%. Hasil uji statistic dengan menggunakan uji wilcoxon didapat nilai $p=$ $0,000(p<0,05)$, berarti terdapat adanya pengaruh pemberian tablet tambah darah (TTD) terhadap kenaikan kadar hemoglobin dengan melibatkan kader posyandu sebagai pengawas minum obat (PMO).

Tabel 1.10. Pengaruh Pendampingan Minum Tablet Tambah Darah (TTD) oleh Kader Posyandu Terhadap Peningkatan Kadar Hb lbu Hamil PadaKelompok Kontrol di Puskesmas Kota Palangka Raya

\begin{tabular}{ccccccc}
\hline $\begin{array}{c}\text { Kelompok } \\
\text { Intervensi }\end{array}$ & Mean & $\mathrm{N}$ & $\begin{array}{c}\text { Standar } \\
\text { Deviasi }\end{array}$ & Minimum & Maksimum & $\mathrm{P}$ \\
\hline $\mathrm{Hb}$ awal & 11,13 & 31 & 1,176 & 10 & 14 & 0,811 \\
$\mathrm{Hb}$ akhir & 11,10 & 31 & 1,479 & 9 & 14 & \\
\hline
\end{tabular}

Pada tabel 1.10. diatas dapat dilihat perbedaan nilai rata -rata kadar hemoglobin awal 11,13 sedangkan kadar hemoglobin akhir nilai rata-ratanya adalah 11,10. Dengan standar deviasi $\mathrm{Hb}$ awal penelitian 1,176 dan standar deviasi akhir penelitian 1,479. Dengan kadar hemoglobin paling rendah pada awal penelitian adalah $10 \mathrm{gr} \%$ dan akhir penelitian kadar hemoglobin paling rendah turun menjadi 9,0 gr.\% Kadar hemoglobin ibu hamil pada awal penelitian paling tinggi adalah 14 gr\% dan akhir penelitian adalah 13 gr\%. Hasil uji statistic dengan menggunakan uji wilcoxon didapat nilai $p=$ $0,811(p<0,05)$, berarti terdapat adanya 
Seri Wahyuni

pengaruh pemberian tablet tambah darah

(TTD) terhadap kenaikan kadar hemoglobin dengan melibatkan kader posyandu sebagai pengawas minum obat (PMO).

\section{PEMBAHASAN}

Dalam penelitian ini, hubungan yang signifikan antara tingkat pengetahuan terhadap kepatuhan ibu hamil mengkonsumsi tablet tambah darah (TTD) sehingga berdampak pada peningkatan kadar hemoglobin ibu hamil. Hal ini berarti makin tinggi tingkat pengetahuan akan semakin patuh pula ibu hamil mengkonsumsi tablet tambah darah (TTD). Hal ini sejalan dengan penelitian yang dilakukan Fuadi dan Bangun yang menyatakan terdapat hubungan yang bermakna antara tingkat pengetahuan ibu hamil tentang anemia defisiensi besi dengan tingkat kepatuhan ibu hamil dalam mengkonsumsi tablet tambah darah (TTD).

Hasil penelitian menunjukkan adanya perbedaan bermakna $\quad(p=0,000)$ Pendampingan Minum Tablet Tambah Darah (TTD) Oleh Kader Posyandu Terhadap Peningkatan Kadar Hb lbu Hamil antara kelompok intervensi dan kelompok kontrol. Ibu hamil dengan pendamping minum obat memiliki kepatuhan yang lebih tinggi daripada tanpa pendamping. Hal ini menunjukkan peran pendamping memiliki peranan yang sangat besar dalam meningkatkan kepatuhan mengkonsumsi tablet tambah darah. Dalam meningkatkan kepatuhan ibu hamil mengkonsumsi tablet tambah darah petugas kesehatan sebaiknya melibatkan kader posyandu sebagai pengawas minum obat sehingga dengan adanya pengawas minum obat pada ibu hamil anemia bisa meningkatkan kepatuhan ibu mengkonsumsi tablet tambah darah sehingga prevalensi angka kejadian anemia dapat diturunkan.

Setelah mengkonsumsi tablet tambah darah selama satu bulan (30 hari) dengan melibatkan kader posyandu sebagai pengawas minum obat, pada 31 orang ibu hamil pada kelompok intervensi, semua ibu hamil mengalami kenaikan kadar hemoglobin berkisar antara 0,2-2,6 gr\% dalam satu bulan konsumsi tablet tambah darah. Kepedulian pendamping dalam memperhatikan dan memonitor konsumsi tablet tambah darah meningkatkan kepatuhan ibu hamil untuk mengkonsumsi obata tambah darah (TTD).

Menurut depkes RI

(1999) pemantauan minum obat adalah seorang yang ditunjuk dan dipercaya untuk mengawasi dan memantau penderita dalam mengkonsumsi obat secara teratur dan tuntas. Tugas pengawas obat diantaranya mengawasi minum obat harian, mencatat obat yang diminum dan mencatat keluhan yang dialami penderita, ikut serta dalam pengambilan obat dan memberi motivasi (Krisnawati, 2010).

Pada kehamilan terjadi terjadi peningkatan akan kebutuhan zat besi sehingga pada waktu hamil ibu sangat dianjurkan untuk mengkonsumsi tablet tambah darah (TTD) yang bertujuan 
Efektifitas Pendampingan Minum Tablet Tambah Darah (TTD) Oleh Kader Posyandu Terhadap Peningkatan Kadar Hb lbu Hamil Di Puskesmas Kota Palangka Raya

mencegah terjadinya anemia pada ibu hamil. Kebutuhan zat besi akan meningkat pada trimester dua dan tiga yaitu sekitar 6,3 mg perhari. Untuk memenuhi kebutuhan zat besi ini dapat diambil dari cadangan zat besi dan peningkatan adaptif penyerapan zat besi melalui saluran cerna. Apabila cadangan zat besi sangat sedikit atau tidak ada sama sekali sedangkan kandungan dan serapan zat besi dari makanan sedikit, maka pemberian suplemen sangat diperlukan untuk memenuhi kebutuhan zat besi ibu hamil (Arisman, 2007). Suplemen oral zat besi dapat menyebabkan mual, muntah, kram lambung, nyeri ulu hati, dan konstipasi (kadang-kadang diare). Dengan efek samping tablet tambah darah yang sangat mengganggu pada ibu hamil sehingga pentingnya pendamping minum obat, salah satu caranya melibatkan kader posyandu untuk memantau, mencatat dan memngingatkan serta member dukungan pada ibu hamil sehingga meningkatkan kepatuhan ibu hamil dalam mengkonsumsi tablet tambah darah (TTD).

Pada kelompok control (tanpa PMO) setelah pemberian tablet tambah darah (TTD) selama 1 bulan, 15 orang $(48,4 \%)$ kadar hemoglobin menurun, 13 orang $(41,9 \%)$ kadar hemoglobin menurun dan 3 orang $(9,5 \%)$ tidak ada perubahan. Salah satau penyebab prevalensi anemia yang masih tinggi karena kurangnya kepatuhan ibu hamil dalam mengkonsumsi tablet tambah darah (TTD). Menurut Silalahi (2007) menyatakan salah satu faktor yang memperngaruhi terjadinya anemia pada ibu hamil yaitu kepatuhan mengkonsumsi tablet besi. Hal ini juga didukung oleh Niven (2002) menyebutkan bahwa salah satu factor yang dapat mempengaruhi kepatuhan penderita dalam menjalani pengobatan adalah dukungan keluarga. Dukungan keluarga berupa mengingatkan minum obat, member motivasi. Alabdin, dkk (2010) yang melakukan penelitian di rumah sakit di riyadh mendapatkan data ibu hamil yang rutin minum tablet tambah darah (TTD) selama trimester II dan III Kadar hemoglobin meningkat sebesar 0,3 gr/dl. Sementara yang tidak patuh kadar hemoglobinya menurun signifikan sekitar 1,4 gr\%.

\section{KESIMPULAN}

Ada perbedaan efektifitas Pendampingan Minum Tablet Tambah Darah (TTD) Oleh Kader Posyandu Terhadap Peningkatan Kadar Hb Ibu Hamil di Puskesmas Kota Palangka Raya. Pada kelompok intervensi memiliki perubahan tingkat pengetahuan yang bermakna $p=$ 0,05 , kelompok kontrol $(p=0,007)$. Tingkat kepatuhan pada kelompok intervensi $(\mathrm{p}=$ 0,000) dan pada kelompok kontrol tidak ada perubahan tingkat kepatuhan $(\mathrm{p}=$ $0,083)$. Hasil uji statistic nilai $p=0,000(p<$ $0,05)$, berarti terdapat adanya pengaruh pemberian tablet tambah darah (TTD) terhadap kenaikan kadar hemoglobin 
dengan melibatkan kader posyandu

sebagai pengawas minum obat (PMO) dibandingkan tanpa pendampingan oleh kader.

\section{SARAN}

Untuk meningkatkan kadar hemoglobin ibu hamil sebaiknya saat ibu hamil mengkonsumsi tablet tambah darah sebaiknya melibatkan kader sebagai pengawas minum obat.

\section{DAFTAR PUSTAKA}

Aditianti,dkk, 2015. Pendampingan Minum Tablet Tambah darah (TTD) Dapat meningkatkan Kepatuhan Konsumsi TTD Pada lbu Hamil Anemia. Volume 38 (1) :71-78

Broek N.Anaemia and Micronutrient deficiencies : reducing maternal death and disability during pregnancy. Br Med Bull. 2003 : 67 : 149-160

Balitbang Kemenkes RI, 2013. Riset Kesehatan Dasar; RISKESDAS. Jakarta, Balitbang Kemenkes RI

Dahlan, M.S., 2012. Langkah-langkah membuat Proposal Penelitian Bidang Kedokteran dan Kesehatan. Sagung seto. Jakarta

-- Statistik Untuk Kedokteran dan Kesehatan. Salemba Medika.Jakarta.

Depkes RI, 1999, Pedoman Penyakit Tuberkulosis Penanggulangannya, Cetakan Empat

Dinas Kesehatan Provinsi Kalimantan Tengah. 2014, Profil Kesehatan Provinsi Kalimantan Tengah Tahun 2014. Palangka Raya : Dinkes Prov. Kalteng

2015, Profil Kesehatan Provinsi Kalimantan Tengah Tahun 2012. Palangka Raya : Dinkes Prov. Kalteng

-2016, Profil Kesehatan Kota

Palangka Raya Tahun 2015.

Palangka Raya : Dinkes Kota
Palangka Raya

Indonesia, Badan Penelitian dan Pengembangan Kesehatan,

Kemenkes RI. Laporan riset kesehatan dasar tahun 2010. Jakarta: Badan Penelitian dan Pengembangan Kesehatan, Kemenkes RI,2010.

Made Bakta, Ketut S, Tjokorda G. Buku ajar ilmu penyakit dalam Hematologianemia defisiensi besi. Edisi ke-5. Jakarta:Interna publishing;2009.h.1127-36.

Novita, L.,dkk. 2012. Pengaruh Pengawas Minum Obat Tablet Fe Pada Ibu Hamil Yang Anemia Terhadap Kenaikan $\mathrm{Hb}$ di Wilayah Kerja Puskesmas Pada Luar Kab. Agam. Volume 8 No.2 : 169-179

Malah, S.R.W., dkk. 2016. Hubungan Kepatuhan Ibu Hamil dalam Mengkonsumsi Tablet Besi (Fe) dengan Kadar Hemoglobin $(\mathrm{Hb})$ di wilayah Kerja Puskesmas Ronomut Kota Manado. Volume 8 No. 2 : 3544.

Maulana, Mirza, 2008, Buku Pegangan Ibu Panduan Lengkap Kehamilan, Kata Hati, Yokyakarta.

Saifuddin, Abdul Bari. 2007.Buku Acuan Nasional Pelayanan Kesehatan Maternal dan Neonatal. Jakarta: Yayasan Bina Pustaka Sarwono Prawirohardjo

Wiknjosastro, Hanifa. 2009.IImu Kebidanan. Jakarta: Yayasan Bina Pustaka Sarwono Prawirohardjo.

Wirakusumah,

Emma S.1999.Perencanaan Menu Anemia Gizi Besi. Jakarta: PT.Pustaka Pembangunan Swadzaya Nusantara. 